\title{
Comparison of the antimicrobial activity of propolis extracts obtained by means of various extraction methods
}

\author{
Katarzyna Pobiega $^{1} \cdot$ Karolina Kraśniewska $^{1}$ (D) Dorota Derewiaka1 ${ }^{1}$ • \\ Małgorzata Gniewosz ${ }^{1}$ (D)
}

Revised: 25 July 2019/Accepted: 7 August 2019/Published online: 30 September 2019

(C) The Author(s) 2019

\begin{abstract}
The objective of the study was to compare the antimicrobial activities of ethanolic propolis extracts obtained using different extraction methods. Extraction of propolis was carried out using $70 \%$ ethanol, propolis to ethanol ratios of 1:10 and 1:5, extraction times of 1 or 7 days, and shaking extraction (SE), ultrasound-assisted extraction (UAE), and ultrasound-assisted shaking extraction (SUAE) methods. A total of 12 propolis extract lyophilizates were obtained. Samples were tested for extraction yield and for total phenol content by the Folin-Ciocalteau colourimetric method, and total flavonoid content using a spectrophotometric method. GLC/MS was used for the identification of chemical compounds in selected extract lyophilizates. Antimicrobial activity against selected bacterial and fungal species was assessed using the disk diffusion method. Propolis extracts obtained as the result of 1-day and 7-day shaking extraction followed by 20 min of ultrasound-assisted extraction (SUAE) had better antimicrobial properties as compared to those obtained by SE or UAE alone. SE and UAE gave lower extraction yields as well as lower phenol and flavonoid contents compared to SUAE. No differences were observed with regard to the qualitative composition of extracts obtained by any of the methods. It is best to obtain the extract using the combined method of 1-day extraction and 20-min sonication.
\end{abstract}

Katarzyna Pobiega

katarzyna_pobiega@sggw.pl

1 Department of Biotechnology, Microbiology and Food Evaluation, Faculty of Food Sciences, Warsaw University of Life Sciences - SGGW, Nowoursynowska 159c str., 02-776 Warsaw, Poland
Keywords Propolis - Extraction method - Sonication · Antimicrobial activity · GC-MS chemical composition

\section{Introduction}

Propolis is produced by bees from tarry and balsamic substances found within flower buds or the bark of deciduous trees, as well as from resins exuding from damaged parts of trees. All these substances are then modified by the addition of wax and apian gland secretions (Bankova et al. 2016b). Propolis is a sticky, resin-like substance of a tan, dark-yellow, orange, brown, or even green color and a very distinctive, intense scent. The composition of propolis varies depending on the region, climate, and prevalent floral species. In moderate climates, various species of poplar and alder trees are used for its production. The resin content (flavonoids and related phenolic acids) of European propolis accounts for about $50 \%$ of its composition. Other ingredients include beeswax (30\%), aromatic and oily substances $(10 \%)$, as well as pollen and mechanical admixtures (5\% each) (Burdock 1998; Bankova et al. 2002). Studies on the chemical composition of propolis have been conducted for many years. Nearly 420 chemical substances have been identified to date in propolis samples originating from different geographical regions of the world. The main constituents include flavones, flavonols, flavanone, and dihydroflavonoids, as well as phenylpropanoid derivatives (Milojković-Opsenica et al. 2016). Thanks to the presence of these substances, propolis is characterized by a broad range of biological activities. Propolis has been documented to possess antibacterial, antifungal, antiviral, antiparasitic, antioxidative, anticancer, anti-inflammatory, antiulcer, and antidiabetic effects (Pasupuleti et al. 2017; Al-Ani et al. 2018). 
Raw propolis is not suitable for food technology, pharmaceutical or cosmetic industry applications due to the high content of impurities which have to be removed (Galeotti et al. 2018). To this end, bioactive constituents of propolis are extracted using organic solvents (GómezCaravaca et al. 2006). The process is expected to eliminate inert materials while preserving the polyphenolic fractions (Gómez-Caravaca et al. 2006). Propolis extracts for use in food production are usually obtained using ethanolic solutions or water (Kubiliene et al. 2015; Bankova et al. 2016a). Extraction with ethanol is particularly suitable for obtaining deparaffinated extracts rich in polyphenolic components. On the other hand, extraction with pure water is suitable for obtaining extracts containing water-soluble phenolic acids (Gómez-Caravaca et al. 2006).

With regard to the techniques for the extraction of raw propolis, room temperature maceration and hot reflux extraction (HRE) were widely used in the past (Trusheva et al. 2007). More advanced techniques used in propolis extraction include microwave-assisted extraction (MAE) (Pellati et al. 2013; Hamzah and Leo 2015), ultrasoundassisted extraction (UAE) (Yeo et al. 2015), and supercritical carbon dioxide extraction (De Zordi et al. 2014). Important advantages of these methods include shorter extraction times, higher extraction yields, and lower solvent consumption compared to conventional methods (Zhou et al. 2009; Zhang et al. 2011).

UAE uses ultrasonic energy $(>20 \mathrm{kHz})$ for extraction using either an ultrasonic bath and/or an ultrasonic probe. It works on the principle of making cavitation bubbles which collapse and produce higher shear, which results in complete extraction (Belwal et al. 2018). Ultrasound accelerates the mixing of the components and facilitate contact between the extracted material and fresh solvent, as well as continuous removal of the stagnant layer barrier. In addition, ultrasound contributes to fragmentation of the extracted material and thus to the enhancement of its exposure to the solvent. It also enlarges the cell pores so that the cells are penetrated by the solvent faster. All the above processes result in accelerated mass exchange between the material and the solvent, resulting in increased extraction yields (Vinatoru et al. 2017).

Harvesting, transporting and packaging are the main sources of microbial contamination. Plant raw materials are carriers of many pathogenic bacteria, such as Escherichia coli and Staphylococcus aureus. In turn, during storage they are exposed to spoilage, which is responsible for the development of fungi such as: Mucor mucedo, Alternaria solani, Colletotrichum gloeosporioides. Improper cleaning or processing of such products before consumption can lead to epidemics. For this reason, all the time looking for natural substances, which on the one hand will protect vegetable raw materials against the development of pathogens and on the other hand against the spoilage caused by fungi (Curifuta et al. 2012; Gniewosz et al. 2014; Kraśniewska et al. 2015; Oni et al. 2018).

The objective of the study was to compare the antimicrobial activities of ethanolic propolis extracts obtained using three different extraction methods. The analysis focused on the effect of the propolis extraction mixture to ethanol weight ratio, time of extraction, as well as shaking and ultrasound-assisted extraction status on the antibacterial efficacy of the obtained propolis extracts. The results were correlated with the determined active substance content for a more rational selection of an optimum procedure to obtain antimicrobial propolis extracts.

\section{Materials and methods}

\section{Materials}

Raw propolis was collected in 2017 from an apiary in Bałtów (southern part of central Poland, $21^{\circ} 32^{\prime} \mathrm{E} ; 51^{\circ} 01^{\prime} \mathrm{N}$ ). The material was loose, dark brown in colour, and had a characteristic scent. Prior to the analysis propolis samples were kept at room temperature in the dark.

\section{Preparations of dry ethanolic extracts of propolis (EEP)}

Two mixtures were prepared as follows: $10 \mathrm{~g}$ of pulverized sample was weighed and dissolved in $100 \mathrm{~mL}$ of $70 \%$ ethanolic solution in a 1:10 (w/v) ratio, while another $10 \mathrm{~g}$ of pulverized sample was weighed and dissolved in $50 \mathrm{~mL}$ of $70 \%$ ethanolic solution in a 1:5 (w/v) ratio. Next, samples were extracted using three different extraction methods. In the first method (SE), samples were shaken (200 rpm) at $28{ }^{\circ} \mathrm{C}$ for 1 or 7 days (SM-30 Control, Edmund Bühler, Germany). In the second method (UAE), samples were subjected to ultrasound. Samples were treated with an Omni Ruptor 4000 sonicator provided by a titanium microtip of diameter $3.8 \mathrm{~mm}$ (OMNI International, the Homogenizer Company, Kennesaw, GA, USA). The sonication process was performed for 30,20 and $10 \mathrm{~min}$ at a power of $210 \mathrm{~W}$ and a frequency of $20 \mathrm{kHz}$. To prevent excessive heating the samples were immediately placed in ice and water baths. Samples were stored at $4{ }^{\circ} \mathrm{C}$. In the third method (SUAE), samples were shaken (200 rpm) at $28{ }^{\circ} \mathrm{C}$ for 1 or 7 days, and then subjected to ultrasound as before (power: $210 \mathrm{~W}$, frequency: $20 \mathrm{kHz}$, Omni-Ruptor 4000, OMNI International Inc., USA with a Titanum $3 / 8^{\prime \prime}$ Dia Solid tip).The obtained dry extracts were filtered using gravity filtration on a Whatman No. 4 filter (Millipore, USA) and then condensed under reduced pressure at $40{ }^{\circ} \mathrm{C}$ (Rotavapor R-215, Büchi, Switzerland). 
The condensed extracts were centrifuged $(3900 \times g / 10 \mathrm{~min}$, centrifuge 5804R, Eppendorf, Poland) to eliminate wax depositing on the tube bottom. Next, the extracts were freeze dried (Alpha 1-4 LSC plus, Christ, Germany) and stored at $4{ }^{\circ} \mathrm{C}$ in dark containers (Bankova et al. 2016a; Graikou et al. 2016; Al-Ani et al. 2018; Al-Qurashi and Awad 2018; Escriche and Juan-Borrás 2018). The aforementioned procedures afforded a total of 12 EEPs (Table 1). Yields of all extraction processes were calculated by dividing the mass of the freeze dried extract by the total mass of raw propolis. Results were expressed in \%. The percentage yields were calculated following Eq. (1):

Yield $=$ (the weight of the extract lyophilisate $) /$ (the weight of crude propolis) $\times 100$

\section{Determination of total flavonoid content}

The total flavonoid content was measured by a modified method (Al-Ani et al. 2018). Initially, $4 \mathrm{mg}$ of lyophilisate was dissolved in $10 \mathrm{~mL}$ of $50 \%$ ethanol. Briefly, $150 \mu \mathrm{L}$ of EEP were mixed with $2 \%$ (w/w) $\mathrm{AlCl}_{3}(100 \mu \mathrm{L})$ in a 96-well microplate, then incubated at $37{ }^{\circ} \mathrm{C}$ for $30 \mathrm{~min}$, and the absorbance at $415 \mathrm{~nm}$ was recorded with a Multiskan Sky Microplate Spectrophotometer (Thermo Fisher Scientific, USA) microplate reader against a blank (a sample without aluminum chloride). Quercetin was used as the standard. Quercetin standard solutions $(0-10 \mathrm{mg} / \mathrm{mL})$ were used for constructing the calibration curve $\left(y=0.3504 x+0.1514 ; \quad R^{2}=0.9936\right)$. The data were expressed as quercetin equivalent $(\mathrm{QE})$ per $\mathrm{g}$ of propolis extract (Al-Ani et al. 2018).

\section{Determination of total phenolic content}

The total phenolic content was measured by a modified method (Singleton et al. 1999). Briefly, $0.1 \mathrm{~g}$ of lyophilisate was dissolved in $10 \mathrm{~mL}$ of $50 \%$ ethanol. $15 \mu \mathrm{L}$ of EEP sample extract and the standard solution (caffeic acid) with a concentration range of $0-200 \mu \mathrm{g} / \mathrm{mL}$ were pipetted into a round bottom 96 -well plate. $240 \mu \mathrm{L}$ of water and $15 \mu \mathrm{L}$ of Folin-Ciocalteu solution were added to the well and left at $24{ }^{\circ} \mathrm{C}$ for $3 \mathrm{~min}$. Then, $30 \mu \mathrm{L}$ of $1.0 \mathrm{M} \mathrm{Na}_{2} \mathrm{CO}_{3}$ solution was added and mixed well. The plate was incubated at $24{ }^{\circ} \mathrm{C}$ for $2 \mathrm{~h}$ in the dark. The absorbances of the reactions were recorded at $765 \mathrm{~nm}$ with a Multiskan Sky Microplate Spectrophotometer (Thermo Fisher Scientific, USA) microplate reader against ethanol as a blank. Based on the measured absorbance of the caffeic acid $(0-700 \mathrm{mg} / \mathrm{mL})$, the calibration curve was constructed $(y=0.0009 x+$ $\left.0.0516 ; R^{2}=0.9811\right)$. The contents of phenolic in the extracts were expressed in terms of caffeic acid equivalent (CAE). The total phenolic content was expressed in mg of caffeic acid equivalent (CAE)/g of extract (Singleton et al. 1999).

Table 1 Extraction yield (\%), total phenols and total flavonoids contents of the propolis extracts from shaking extraction (SE), ultrasonicassisted extraction (UAE) and shaking with ultrasonic-assisted extraction (SUAE)

\begin{tabular}{|c|c|c|c|c|c|c|}
\hline Trial abbreviation & $\begin{array}{l}\text { Shaking time } \\
\text { S (days) }\end{array}$ & $\begin{array}{l}\text { Ratio of propolis } \\
\text { to ethanol }\end{array}$ & $\begin{array}{l}\text { Time of sonication } \\
U \text { (min) }\end{array}$ & $\begin{array}{l}\text { Extraction } \\
\text { yield }(\%)\end{array}$ & $\begin{array}{l}\text { Total phenols } \\
(\mathrm{mg} \mathrm{CAE} / \mathrm{g}) * *\end{array}$ & $\begin{array}{l}\text { Total flavonoids } \\
(\mathrm{mg} \mathrm{QE} / \mathrm{g})^{* * *}\end{array}$ \\
\hline \multicolumn{7}{|l|}{ SE } \\
\hline S7-10-U0* & 7 & $1: 10$ & 0 & $9.71 \pm 0.76^{\mathrm{d}}$ & $90.83 \pm 6.27^{\mathrm{c}}$ & $14.48 \pm 0.04^{\mathrm{c}}$ \\
\hline S7-5-U0 & 7 & $1: 5$ & 0 & $7.71 \pm 0.65^{\mathrm{e}}$ & $78.77 \pm 6.73^{\mathrm{d}, \mathrm{e}}$ & $13.09 \pm 0.07^{\mathrm{e}}$ \\
\hline S1-10-U0 & 1 & $1: 10$ & 0 & $10.76 \pm 0.84^{\mathrm{c}, \mathrm{d}}$ & $92.36 \pm 2.34^{\mathrm{b}, \mathrm{c}}$ & $13.88 \pm 0.15^{\mathrm{d}}$ \\
\hline S1-5-U0 & 1 & $1: 5$ & 0 & $5.76 \pm 0.51^{\mathrm{f}}$ & $85.87 \pm 2.71^{\mathrm{c}, \mathrm{d}}$ & $12.57 \pm 0.03^{\mathrm{f}}$ \\
\hline \multicolumn{7}{|l|}{ UAE } \\
\hline S0-10-U10 & 0 & $1: 10$ & 10 & $8.35 \pm 0.79^{\mathrm{e}}$ & $76.03 \pm 1.43^{\mathrm{e}}$ & $11.01 \pm 0.09^{\mathrm{g}}$ \\
\hline S0-10-U20 & 0 & $1: 10$ & 20 & $10.73 \pm 0.94^{\mathrm{c}, \mathrm{d}}$ & $81.76 \pm 1.95^{\mathrm{d}}$ & $13.12 \pm 0.09^{\mathrm{e}}$ \\
\hline S0-10-U30 & 0 & $1: 10$ & 30 & $11.86 \pm 1.08^{\mathrm{c}}$ & $98.74 \pm 2.33^{\mathrm{b}}$ & $15.07 \pm 0.03^{\mathrm{b}}$ \\
\hline S0-5-U20 & 0 & $1: 5$ & 20 & $10.08 \pm 0.71^{\mathrm{d}}$ & $89.61 \pm 2.06^{\mathrm{c}, \mathrm{d}}$ & $13.75 \pm 0.03^{\mathrm{d}}$ \\
\hline \multicolumn{7}{|l|}{ SUAE } \\
\hline S7-10-U20 & 7 & $1: 10$ & 20 & $15.92 \pm 1.34^{\mathrm{a}}$ & $105.29 \pm 1.93^{\mathrm{a}}$ & $15.69 \pm 0.10^{\mathrm{a}}$ \\
\hline S7-5-U20 & 7 & $1: 5$ & 20 & $11.64 \pm 0.86^{\mathrm{c}}$ & $94.64 \pm 1.74^{\mathrm{b}, \mathrm{c}}$ & $15.71 \pm 0.04^{\mathrm{a}}$ \\
\hline S1-10-U20 & 1 & $1: 10$ & 20 & $14.19 \pm 0.98^{\mathrm{b}}$ & $104.16 \pm 4.16^{\mathrm{a}}$ & $15.23 \pm 0.04^{\mathrm{b}}$ \\
\hline S1- 5-U20 & 1 & $1: 5$ & 20 & $10.04 \pm 0.88^{\mathrm{d}}$ & $98.74 \pm 2.95^{\mathrm{b}}$ & $15.04 \pm 0.06^{\mathrm{b}}$ \\
\hline
\end{tabular}

*S-shaking time (S7-7 days, S1-1 day, S0-without shaking), 5, 10-ratio of propolis to ethanol (5-ratio 1:5 and 10-ratio1:10), U-time of sonication (U30-30 min, U20-20 min, U10-10 min, U0-without sonication); **quercetin equivalent (QE)/g of propolis extract, ***caffeic acid equivalent $(\mathrm{CAE}) / \mathrm{g}$ of propolis extract. $\mathrm{a}, \mathrm{b}, \mathrm{c}$ - mean values in the same column with different letters differ significantly $(p \leq 0.05)$ 


\section{Gas chromatography/mass spectrometry (GC/MS) analysis of propolis extracts}

GC/MS was performed on a Shimadzu GCMS-QP2010S (Shimadzu, Japonia) equipped with a $30 \mathrm{~m} \mathrm{ZB-5}$ capillary column with a (5\% phenyl)-polymethyl siloxane stationary phase, film thickness of $0.25 \mu \mathrm{m}$, diameter $0.25 \mathrm{~mm}$. Briefly, $1 \mathrm{~g}$ of lyophilisate was dissolved in $10 \mathrm{~mL}$ of $50 \%$ ethanol. About 25-40 mg extract was evaporated under nitrogen conditions and derivatized with $50 \mu \mathrm{g}$ pirydine, $100 \mu \mathrm{L}$ BSTFA and $1 \%$ TMCS, and after $24 \mathrm{~h}$ was dissolved in $1 \mathrm{~mL}$ hexane. $1 \mu \mathrm{L}$ of the sample was injected with a split mode (split ratio 1:25) with the carrier gas helium at a flow rate of $0.05 \mathrm{~mL} / \mathrm{min}$. The capillary column was coupled to a quadrupole mass spectrometer and the optimized instrumental parameters were as follows: Injector temperature $\left(230^{\circ} \mathrm{C}\right)$, head pressure $(53.1 \mathrm{kPa})$, and transfer line heater $\left(250^{\circ} \mathrm{C}\right)$. The mass spectra were noted according to the following recommendations: Scan range (Routine): $\mathrm{m} / \mathrm{z}$ 35-450, scan time: (Routine) $1 \mathrm{~s}$, electron energy: $70 \mathrm{eV}$, source temperature: $220{ }^{\circ} \mathrm{C}$, filament delay time: (Routine) $3 \mathrm{~min}$; with GC MS Postrum Analysis (Kartal et al. 2002; Al-Ani et al. 2018).

\section{Determination of antimicrobial activity of ethanolic extracts of propolis}

\section{Test strains}

Strains used in the tests included bacteria (Staphylococcus aureus ATCC 25923 and Escherichia coli O157 ATCC 700728) and fungi (Candida krusei ATCC 14243, Mucor mucedo ATCC 38694, Alternaria solani ATCC 16022, Colletotrichum gloeosporioides DSM 62146) obtained from the American Type Culture Collection or from the Leibniz Institute DSMZ-German Collection of Microorganisms and Cell Cultures., as well as moulds Colletotrichum gloeosporioides DSM 62146 obtained from the Leibniz Institute DSMZ-German Collection of Microorganisms and Cell Cultures. The strains were stored in 20\% glycerol at $-80{ }^{\circ} \mathrm{C}$ in a freezer. The bacterial strains were cultured on Nutrient Agar (NA, BTL, Poland) at $37^{\circ} \mathrm{C}$ for $24 \mathrm{~h}$. Bacterial inocula were prepared in sterile saline $(0.85 \% \mathrm{NaCl})(\mathrm{w} / \mathrm{v})$ solution with the quantity corresponding to 0.5 McFarland $\left(\sim 1 \times 10^{8} \mathrm{cfu} / \mathrm{mL}\right)$. Yeast was cultured on Sabouraud Dextrose Agar (SDA, BTL, Poland) at $28{ }^{\circ} \mathrm{C}$ for $48 \mathrm{~h}$. The yeast inoculum was prepared in a sterile $0.85 \% \mathrm{NaCl}(\mathrm{w} / \mathrm{v})$ solution to reach a population of approximately $\sim 1 \times 10^{6} \mathrm{CFU} / \mathrm{mL}$, using a hemacytometer. The mould conidia and spores were obtained from mycelium grown on SDA after incubation at $25{ }^{\circ} \mathrm{C}$ for 14 days. Spore or conidium suspensions were prepared in sterile $0.85 \% \mathrm{NaCl}$ containing $0.1 \%$ Tween 80 to achieve $\sim 1 \times 10^{6}$ spores $/ \mathrm{mL}$, using a hemacytometer (Gniewosz et al. 2014).

\section{Disc-diffusion method}

Antimicrobial activities of EEP were determined with a disc-diffusion method (Standards Institute Clinical Laboratory (CLSI) 2006; Gavanji and Larki 2017). Briefly, $1 \mathrm{~g}$ of lyophilisate was dissolved in $10 \mathrm{~mL}$ of $50 \%$ ethanol. Sterile cellulose discs ( $6 \mathrm{~mm}$ diameter) were impregnated with $20 \mu \mathrm{L}$ EEP (density $100 \mathrm{mg} / \mathrm{mL}$ ). Equal EEP contents were obtained, and these were $2 \mathrm{mg}$ d.w./disc. The suspensions of tested bacteria were spread evenly on the surface of MHA plates, and yeasts or mould spore suspensions on SDA plates. After $5 \mathrm{~min}$, discs with EEP were placed on the surfaces of the inoculated plates. The plates with bacteria were incubated at $37{ }^{\circ} \mathrm{C}$ for $24 \mathrm{~h}$, with yeast at $28{ }^{\circ} \mathrm{C}$ for $48 \mathrm{~h}$, and those with moulds at $25{ }^{\circ} \mathrm{C}$ for $72 \mathrm{~h}$. After incubation, the diameter of growth inhibition around the discs was measured. The results were expressed in millimeters. All tests were performed in triplicate and a new inoculum was prepared for each replicate, and the standard deviations were determined (Standards Institute Clinical Laboratory (CLSI) 2006; Gavanji and Larki 2017).

\section{Statistical analysis}

Statistical tests were performed using the Statistica version 10PL computer program (StatSoft Inc., Poland). One-way analysis of variance was carried out. The significance of differences between mean values was assessed using the Tukey-test at a significance level of $\alpha=0.05$.

\section{Results}

\section{Comparison of extraction yields}

The yields of extractions varied between 5.76 and $15.92 \%$ depending on the method (Table 1). The yields of SE processes ranged from $5.76 \pm 0.51$ to $10.76 \pm 0.84 \%$. Statistically higher yields were observed for more diluted (1:10) as compared to less diluted (1:5) samples. The yields of UAE procedures increased with process duration and ranged from $8.35 \pm 0.79 \%$ (S0-10-U10) to $11.86 \pm 1.08 \%$ (S0-10-U30). The propolis to solvent ratio had no impact on the efficacy of extraction using this method. Extraction yields obtained using the SUAE method were higher than those obtained by either of the other methods. The highest yields of extraction were observed after 7 days of shaking extraction of samples diluted in a 1:10 ratio and 

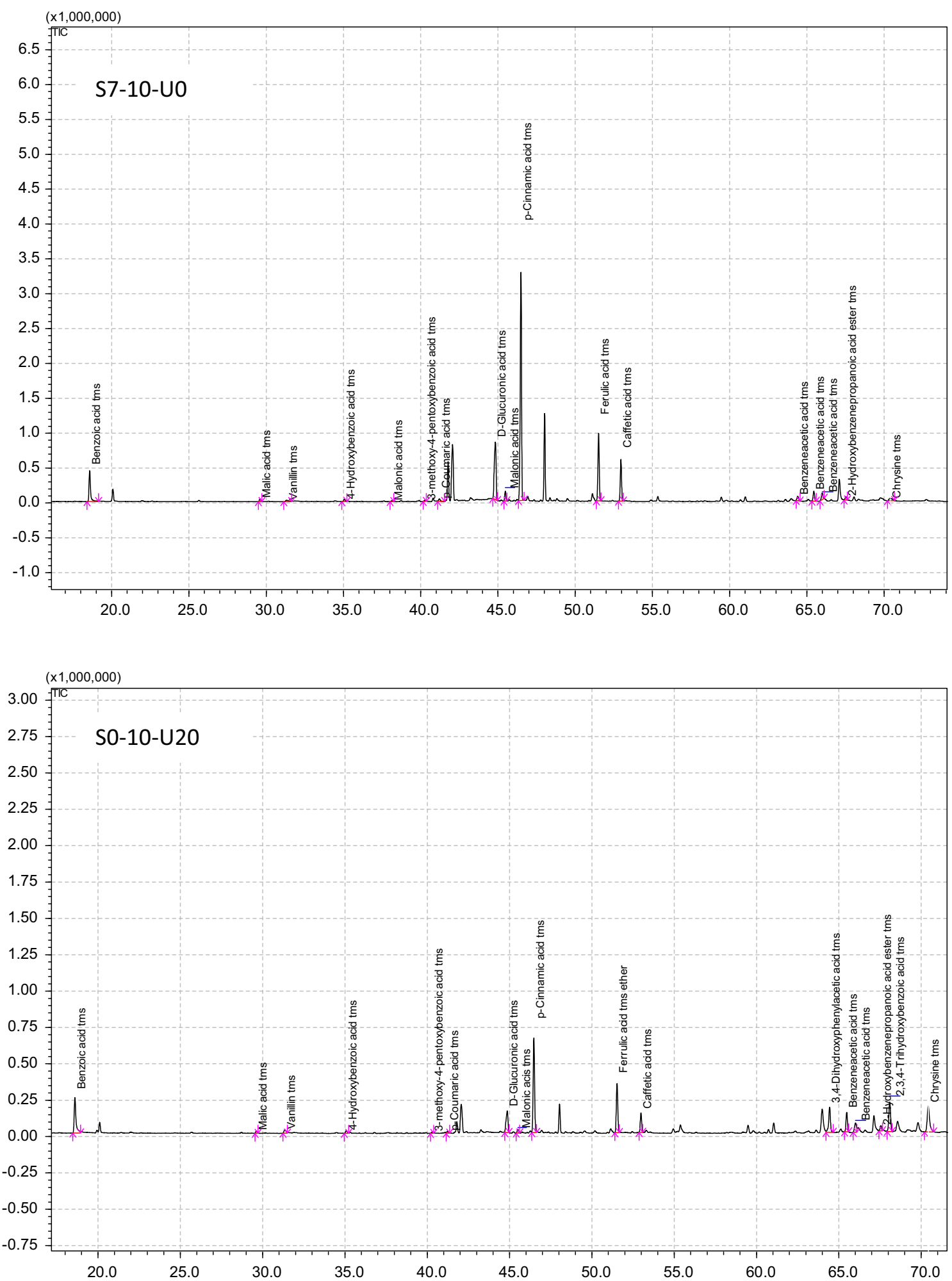

Fig. 1 GLC/MS profil of chemical compounds of EEPs. *S—shaking time (S7-7 days, S0-without shaking), 10—ratio of propolis to ethanol (1:10), U-time of sonication (U20-20 min, U0-without sonication)

subsequently subjected to UAE (S7-10-U20), as well as after 1 day of shaking extraction in otherwise similar conditions (S1-10-U20). Larger extraction yields were observed for the propolis to solvent ratio of 1:10 (compared to the $1: 5$ ratio). 


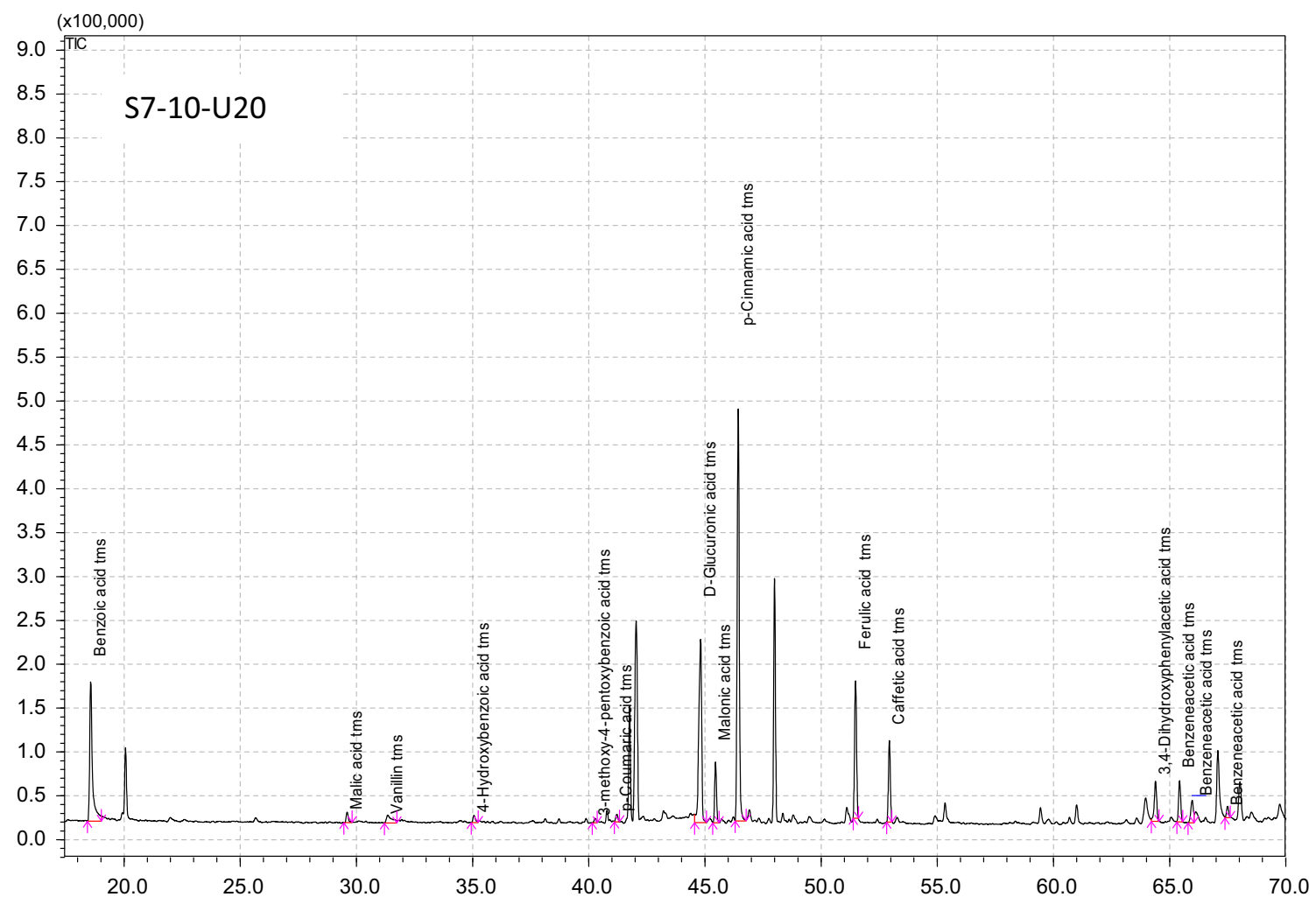

Fig. 1 continued

\section{Comparison of total phenol and flavonoid content of EEPs}

Table 1 presents total contents of polyphenols and flavonoids in ethanolic extracts of propolis obtained using the three extraction methods. The mean content of phenols following SE ranged from $78.77 \mathrm{mg} \mathrm{CAE} / \mathrm{g}$ (S7-5-U0) to $90.83 \mathrm{mg}$ CAE/g (S7-10-U0). The mean content of flavonoids in the same extracts ranged from $12.57 \mathrm{mg} \mathrm{QE} / \mathrm{g}$ (S15-U0) to $14.48 \mathrm{mg}$ QE/g (S7-10-U0). Overall, extracts obtained after 7 days of SE of samples with the propolis to solvent ratio of 1:10 were richer in flavonoids, whereas extracts obtained after 1 or 7 days of extraction of $1: 10$ samples were richer in phenols. For samples obtained using UAE, the content of phenols and flavonoids was found to increase along with the ultrasonication times. After $30 \mathrm{~min}$ of ultrasonication, the extract (S0-10-U30) with the highest polyphenol (98.74 mg CAE/g) and flavonoid content (15.07 mg QE/g) was obtained, whereas the extract subjected to only $10 \mathrm{~min}$ of ultraconication (S0-10-U10) presented with the lowest amounts of both classes of compounds: $76.03 \mathrm{mg} \mathrm{CAE} / \mathrm{g}$ and $11.01 \mathrm{mg} \mathrm{QE} / \mathrm{g}$, respectively. Extracts obtained using the third method consisting in shaking extraction performed for 7 days and subsequent ultrasonic-assisted extraction lasting $20 \mathrm{~min}$ (S7-10-U20 and S7-5-U20) were found to contain statistically higher $(p \leq 0.05)$ quantities of flavonoids compared to the extracts obtained using the previously described methods. Statistically higher quantities of phenols $(p \leq 0.05)$ were observed for extracts S7-10-U20 (105.29 mg CAE/g) and S1-10-U20 (104.16 mg CAE/g). The content of flavonoids within the extracts obtained using the SUAE method ranged between 15.04 and $15.69 \mathrm{mg} \mathrm{QE} / \mathrm{g}$.

\section{Comparison of the content of identified components in individual EEPs}

Three extracts, one per extraction method, were selected for the analysis of chemical composition using the GLC/ MS technique. These included S7-10-U0, obtained following 7 days of shaking extraction, S0-10-U20 obtained after 20 min of ultrasound-assisted extraction, and S7-10U20, obtained following 7 days of shaking extraction and $20 \mathrm{~min}$ of ultrasound-assisted extraction. Although the extracts differed in their total phenol and flavonoid contents, the components of these classes constituted the majority of all products. Figure 1 presents the chromatograms of chemical composition, while Table 2 compares the quantities of identified compounds in individual extracts. All selected extracts contained phenolic acids, including $p$-cinnamic acid, ferulic acid and caffeic acid, as 
Table 2 Chemical components identified in propolis extracts by GLC/MS method

\begin{tabular}{|c|c|c|c|}
\hline \multirow[t]{2}{*}{ Chemical compound } & \multicolumn{3}{|c|}{ Propolis extract } \\
\hline & S7-10-U0 ${ }^{a}$ & S0-10-U20 & S7-10-U20 \\
\hline Acetic acid tms & + & - & - \\
\hline 3,4-Dihydroxyphenylacetic acid tms & - & + & - \\
\hline Benzeneacetic acid tms & + & + & + \\
\hline Benzoic acid tms & + & + & + \\
\hline 2,3,4-Trihydroxybenzoic acid tms & - & + & - \\
\hline 3-Methoxy-4-pentoxybenzoic acid tms & + & + & + \\
\hline 4-Hydroxybenzoic acid tms & + & + & + \\
\hline Butanoic acid tms & - & + & - \\
\hline Caffeic acid tms & + & + & + \\
\hline D-glucuronic acid tms & + & + & + \\
\hline Ferulic acid & + & + & + \\
\hline Hexadecanoic acid tms & + & - & - \\
\hline Malic acid tms & + & + & + \\
\hline Malonic acid tms & + & + & + \\
\hline$p$-Cinnamic acid tms & + & + & + \\
\hline 2-Furanacetaldehyde tms & + & - & + \\
\hline 2-Hydroxybenzenepropanoic acid ester tms & + & + & + \\
\hline Ferulic acid tms ether & + & + & + \\
\hline Vanillin tms & + & + & + \\
\hline D-xylose tms & - & + & - \\
\hline Maltose tms & + & + & + \\
\hline Mannose tms & + & + & - \\
\hline Sorbose tms & + & + & + \\
\hline Sucrose tms & + & + & + \\
\hline Chrysine tms & + & + & - \\
\hline
\end{tabular}

${ }^{\mathrm{a}} \mathrm{S}$ - shaking time (S7-7 days, S0-without shaking), 10-ratio of propolis to ethanol (1:10), U-time of sonication (U20-20 min, U0-without sonication) well as carboxylic acids such as benzoic acid, benzeneacetic acid, 4-hydroxybenzoic acid, 3-methoxy-4-pentoxybenzoic acid, D-glucuronic acid, malic acid, and malonic acid. Likewise, all extracts contained acid derivatives such as 2-hydroxybenzenepropanoic acid ester and ferulic acid ether and four sugars, namely vanillin, maltose, sorbose and sucrose. An antibacterial flavonoid, chrysin, was present only in two of the extracts.

\section{Comparison of antimicrobial activities of EPPs}

Table 3 presents the sizes of strain growth inhibition zones for extracts obtained using each of the three methods. All extracts were found to present with antimicrobial activity. The inhibitory activity of extracts varied not only depending on the extraction method, but also on the test species included in the assay. $S$. aureus was more sensitive to the study extracts than any other strain.

The sizes of strain growth inhibition zones for the propolis extract obtained using the shaking extraction technique ranged from $9.66 \mathrm{~mm}$ to $25.3 \mathrm{~mm}$. Inhibition zones for $S$. aureus were larger $(20.24-25.38 \mathrm{~mm})$ than those for other microorganisms (9.66-17.28 mm). Higher variability of EEP activity was observed with regard to $S$. aureus, C. gloeosporioides, and A. solani, while low variability was observed with regard to E. coli, C. krusei, and M. mucedo. A significant impact of the propolis to solvent ratio was observed for the extract obtained in 7-day shaking extraction on the antimicrobial activity against all study strains. No such impact was observed for the extract obtained in 1 day shaking extraction with regard to $E$. coli, C. krusei, C. gloeosporioides, and M. mucedo, but not with regard to $S$. aureus and $A$. solani.

Samples obtained in ultrasound-assisted extraction were found to have antimicrobial activity similar to those obtained in shaking extraction. Most strain growth inhibition zone sizes ranged between 9.95 and $26.89 \mathrm{~mm}$. The longer the time of ultrasonication, the higher the antimicrobial activity of the extracts. The largest strain growth inhibition zones were obtained in all tested strains for the 
Table 3 Antimicrobial activity of propolis extracts from shaking extraction (SE), ultrasonic-assisted extraction (UAE) and shaking with ultrasonic-assisted extraction (SUAE)

\begin{tabular}{|c|c|c|c|c|c|c|}
\hline Trial abbreviation & $\begin{array}{l}\text { S. aureus } \\
\text { Zone of inhibition }\end{array}$ & $\begin{array}{l}\text { E. coli } \\
\left.\mathrm{nm} \pm \mathrm{SD}^{* *}\right)\end{array}$ & C. krusei & C. gloeosporioides & M. тисеdо & A.solani \\
\hline \multicolumn{7}{|l|}{ SE } \\
\hline S7-10-U0* & $20.24 \pm 0.76^{\mathrm{a} * * *}$ & $17.28 \pm 0.44^{\mathrm{c}}$ & $13.89 \pm 0.74^{\mathrm{b}, \mathrm{c}, \mathrm{d}}$ & $16.61 \pm 0.32^{\mathrm{e}, \mathrm{f}, \mathrm{g}}$ & $12.64 \pm 0.13^{\mathrm{a}}$ & $9.66 \pm 0.25^{\mathrm{a}}$ \\
\hline S7-5-U0 & $24.45 \pm 0.96^{\mathrm{c}}$ & $14.73 \pm 0.29^{\mathrm{a}}$ & $15.27 \pm 1.21^{\mathrm{e}, \mathrm{f}}$ & $16.08 \pm 0.69^{\mathrm{d}, \mathrm{e}, \mathrm{f}}$ & $13.41 \pm 0.24^{\mathrm{a}, \mathrm{b}}$ & $13.01 \pm 0.38^{\mathrm{c}}$ \\
\hline S1-10-U0 & $25.38 \pm 1.05^{\mathrm{c}, \mathrm{d}}$ & $15.72 \pm 0.22^{\mathrm{b}}$ & $13.45 \pm 0.85^{\mathrm{a}, \mathrm{b}}$ & $14.62 \pm 0.46^{\mathrm{b}, \mathrm{c}, \mathrm{d}}$ & $14.62 \pm 1.04^{\mathrm{b}, \mathrm{c}, \mathrm{d}}$ & $15.37 \pm 0.25^{\mathrm{f}}$ \\
\hline S1-5-U0 & $22.43 \pm 0.76^{\mathrm{b}}$ & $15.88 \pm 0.17^{\mathrm{b}}$ & $13.67 \pm 0.88^{\mathrm{a}, \mathrm{b}, \mathrm{c}}$ & $14.03 \pm 0.85^{\mathrm{a}, \mathrm{b}, \mathrm{c}}$ & $13.46 \pm 0.76^{\mathrm{a}, \mathrm{b}}$ & $11.48 \pm 0.86^{\mathrm{b}}$ \\
\hline \multicolumn{7}{|l|}{ UAE } \\
\hline S0-10-U10 & $22.31 \pm 0.82^{\mathrm{b}}$ & $15.06 \pm 0.41^{\mathrm{a}, \mathrm{b}}$ & $12.81 \pm 0.41^{\mathrm{a}}$ & $14.57 \pm 0.21^{\mathrm{b}, \mathrm{c}, \mathrm{d}}$ & $13.99 \pm 0.58^{\mathrm{a}, \mathrm{b}, \mathrm{c}}$ & $9.95 \pm 0.50^{\mathrm{a}}$ \\
\hline S0-10-U20 & $25.61 \pm 0.98^{\mathrm{c}, \mathrm{d}, \mathrm{e}}$ & $17.91 \pm 0.61^{\mathrm{c}, \mathrm{d}}$ & $14.79 \pm 0.84^{\mathrm{d}, \mathrm{e}}$ & $15.74 \pm 1.16^{\mathrm{c}, \mathrm{d}, \mathrm{e}}$ & $16.42 \pm 0.25^{\mathrm{e}, \mathrm{f}}$ & $12.67 \pm 0.60^{\mathrm{b}, \mathrm{c}}$ \\
\hline S0-10-U30 & $26.74 \pm 0.74^{\mathrm{e}, \mathrm{f}, \mathrm{g}}$ & $20.02 \pm 0.50^{\mathrm{f}}$ & $15.95 \pm 0.73^{\mathrm{f}}$ & $17.65 \pm 0.22^{\mathrm{f}, \mathrm{g}}$ & $17.06 \pm 0.17^{\mathrm{g}}$ & $14.48 \pm 1.00^{\mathrm{d}, \mathrm{e}}$ \\
\hline S0-5-U30 & $26.89 \pm 0.67^{\mathrm{f}, \mathrm{g}}$ & $14.71 \pm 0.27^{\mathrm{a}}$ & $15.54 \pm 0.69^{\mathrm{e}, \mathrm{f}}$ & $13.40 \pm 0.36^{\mathrm{a}, \mathrm{b}}$ & $13.09 \pm 1.05^{\mathrm{a}, \mathrm{b}}$ & $11.69 \pm 0.10^{\mathrm{b}}$ \\
\hline \multicolumn{7}{|l|}{ SUAE } \\
\hline $\mathrm{S} 7-10-\mathrm{U} 20$ & $27.07 \pm 0.87^{\mathrm{f}, \mathrm{g}}$ & $19.09 \pm 0.32^{\mathrm{d}, \mathrm{e}}$ & $15.19 \pm 0.43^{\mathrm{e}, \mathrm{f}}$ & $18.07 \pm 0.61^{\mathrm{h}}$ & $15.51 \pm 1.10^{\mathrm{d}, \mathrm{e}}$ & $14.70 \pm 0.66^{\mathrm{d}, \mathrm{e}}$ \\
\hline S7-5-U20 & $26.49 \pm 1.73^{\mathrm{d}, \mathrm{e}, \mathrm{f}, \mathrm{g}}$ & $18.01 \pm 0.15^{\mathrm{c}, \mathrm{d}}$ & $14.84 \pm 0.55^{\mathrm{d}, \mathrm{e}}$ & $15.88 \pm 0.90^{\mathrm{c}, \mathrm{d}, \mathrm{e}}$ & $15.74 \pm 0.26^{\mathrm{d}, \mathrm{e}}$ & $13.75 \pm 0.40^{\mathrm{c}, \mathrm{d}}$ \\
\hline S1-10-U20 & $26.36 \pm 0.54^{\mathrm{d}, \mathrm{e}, \mathrm{f}, \mathrm{g}}$ & $18.63 \pm 0.30^{\mathrm{d}}$ & $15.11 \pm 0.86^{\mathrm{e}, \mathrm{f}}$ & $17.26 \pm 0.72^{\mathrm{f}, \mathrm{g}}$ & $16.30 \pm 0.72^{\mathrm{e}, \mathrm{f}}$ & $13.88 \pm 0.36^{\mathrm{c}, \mathrm{d}}$ \\
\hline S1-5-U20 & $25.70 \pm 0.79^{d}$ & $17.20 \pm 0.39^{c}$ & $14.62 \pm 0.82^{\mathrm{c}, \mathrm{d}, \mathrm{e}}$ & $15.18 \pm 0.70^{\mathrm{c}, \mathrm{d}, \mathrm{e}}$ & $14.98 \pm 0.89^{\mathrm{c}, \mathrm{d}}$ & $13.83 \pm 0.65^{\mathrm{c}, \mathrm{d}}$ \\
\hline
\end{tabular}

*S—shaking time (S7-7 days, S1-1 day, S0-without shaking), 5, 10-ratio of propolis to ethanol (5-ratio 1:5 and 10-ratio 1:10), U-time of sonication (U30-30 min, U20-20 min, U10-10 min, U0-without sonication), **Each value is the mean for three $(n=3)$ replicates, ***a, b, cmean values in the same column with different letters differ significantly $(p \leq 0.05)$

extract subjected to $30 \mathrm{~min}$ of sonication (S0-10-30U). Samples subjected to 20 and $10 \mathrm{~min}$ of ultrasonication presented with lower strain growth inhibition activities. Reduction in the propolis to ethanol ratio from 1:10 to 1:5 led to reduced activity of the extract (S0-5-U20) against E. coli, C. gloeosporioides, and M. mucedo compared to the inhibitory activity of S0-10-U20.

Samples subjected to shaking extraction followed by ultrasound-assisted extraction (SUAE) were characterized by identical inhibitory activities against $S$. aureus, E. coli, C. krusei, and M. mucedo, with no statistical differences being observed in inhibition zone sizes $(p>0.05)$. The propolis to solvent ratio was found to affect the antifungal activity of extracts against $C$. gloeosporioides and $A$. solani, with growth inhibition zones being significantly larger $(p \leq 0.05)$ for $1: 10$ extracts as compared to $1: 5$ extracts. No effect of shaking time on antifungal activity of extracts was observed.

\section{Discussion}

In order to be suitable for use in the food industry, propolis extracts should present with high biological activity. Thus, an appropriate method for the preparation of crude propolis extracts is of key importance. In our study we compared the antimicrobial activity of propolis extracts obtained using three different methods: traditional shaking extraction (SE), ultrasound-assisted extraction (UAE), and shaking extraction combined with ultrasound-assisted extraction (SUAE). We observed that extracts obtained by shaking extraction combined with ultrasound-assisted extraction (SUAE) or ultrasound-assisted extraction (UAE) presented with higher antimicrobial activity than extracts obtained by traditional shaking extraction (SE) only. This was due to the higher overall extraction yield and higher contents of phenols and flavonoids in these extracts. Shaking extraction lasting 1 day followed by $20 \mathrm{~min}$ of ultrasound-assisted extraction (SUAE) increased the extraction of phenols by 15 and $23 \%$ and the extraction of flavonoids by 8 and $14 \%$ as compared to SE and UAE, respectively. The content of phenols and flavonoids determines the antimicrobial and antioxidative activity of propolis (Jug et al. 2014). Khacha-ananda et al. observed that the extraction of propolis by means of sonication techniques led to the total content of phenolic and flavonoid compounds being higher than in the case of maceration (Khacha-ananda et al. 2013). In other studies, the authors reported that UAE was superior to 2-day shaking extraction in terms of the extraction of flavonoids but inferior to the latter in terms of the extraction of phenolic compounds. Despite different content of bioactive compounds in the propolis extracts, no significant impact of these differences on antimicrobial properties was observed as all extracts inhibited the bacterial growth with similar strengths (Luján et al. 2018). Likewise, in the studies by 
Yeo et al. (2015), an extract with a considerably higher content of bioactive compounds obtained in an ultrasoundassisted procedure presented with a growth inhibition effect being only slightly higher for Staphylococcus epidermidis and Bacillus subtilis and lower for E. coli as compared to an extract obtained in a traditional, 1-day maceration process. This phenomenon may be explained by the complexity of composition of the propolis extracts and interactions between the effects of components which may be present even at very low levels (Bankova et al. 2016a).

The 1:10 versus 1:5 propolis to solvent ratio had no effect on the antimicrobial activity against most tested strains only for SUAE extracts. Extracts obtained by means of SE and UAE presented with lower inhibition of tested strains (S. aureus, C. gloeosporioides) when the propolis to solvent ratio was $1: 5$ than when the ratio was $1: 10$. The impact of the extraction mixture ethanol content on the quantities of bioactive agents within the final extract is difficult to explain as most researchers believe that the propolis to ethanol ratio has no impact on the extraction of most propolis components (Trusheva et al. 2007; Khachaananda et al. 2013).

Our results are in line with earlier studies which suggested that UAE significantly reduced the extraction times (Trusheva et al. 2007; Khacha-ananda et al. 2013; Jug et al. 2014). In addition, our studies showed that the longer the ultrasonication process, the stronger the inhibitory effect of extracts against test microorganisms. This phenomenon may be explained by the content of flavonoids and phenols being higher for longer sonication times.

Isidorov et al. (2014) investigated the chemical composition of various European propolis. In the Polish propolis, there are cinnamon acids and their derivatives, such as ferulic or coffeic acids. The content of cinnamon acids and their derivatives were estimated at $12 \%$. Esters of cinnamon constituted $19.3 \%$ of the chemical composition of the extract. The content of chrysin was marked at $5.1 \%$. The research on the chemical composition of Polish propolis was also carried out by Popova et al. (2017). Among the marked aromatic acids, the highest content was $p$ coumaric acid (5.3\%) and ferulic acid (3.4\%) and chrysin (3\%) of all ingredients. Over a half of the chemical composition were esters of cinnamic acid and its derivatives. In ethanol extracts of propolis examined by Szliszka et al. (2013) also identified phenolic acids and their derivatives, and chrysin accounted for $6.56 \mathrm{mg} / \mathrm{g}$ of propolis.

The extraction method had no impact on the qualitative composition of propolis extracts. The antimicrobial properties of propolis are believed to be due to the presence of phenolic acids, including ferulic acid, cinnamic acid, benzoic acid, and benzeneacetic acid; these compounds were present in the tested extracts. We support the view that the biological activity of propolis is due to the synergistic action of all ingredients, not a specific chemical or group of ingredients (Boisard et al. 2015). Takasi et al. (1994) demonstrated that high levels of phenolic compounds lead to the denaturation of enzymes and consequently to bacterial cell death.

\section{Conclusion}

The extraction method affects the antimicrobial properties of extracts, extraction yields, as well as the contents of phenolic and flavonoid compounds. Antimicrobial activity of extracts obtained by 1-day shaking extraction followed by ultrasonication was higher than extracts obtained by only traditional or ultrasound-assisted extraction. SE and UAE gave lower extraction yields as well as lower phenol and flavonoid contents compared to SUAE. SUAE gave a higher yield and higher content of phenols and flavonoids than SE and UEA.

Acknowledgements This Project was carried out with financial support from the Warsaw University of Life Sciences-SGGW under research Grant No. 505-10-092800-P00210-99.

Open Access This article is distributed under the terms of the Creative Commons Attribution 4.0 International License (http://crea tivecommons.org/licenses/by/4.0/), which permits unrestricted use, distribution, and reproduction in any medium, provided you give appropriate credit to the original author(s) and the source, provide a link to the Creative Commons license, and indicate if changes were made.

\section{References}

Al-Ani I, Zimmermann S, Reichling J, Wink M (2018) Antimicrobial activities of European propolis collected from various geographic origins alone and in combination with antibiotics. Medicines. https://doi.org/10.3390/medicines5010002

Al-Qurashi AD, Awad MA (2018) Postharvest ethanolic extract of propolis treatment affects quality and biochemical changes of 'Hindi-Besennara' mangos during shelf life. Sci Hortic (Amsterdam) 233:520-525. https://doi.org/10.1016/j.scienta.2017.12. 030

Bankova V, Popova M, Bogdanov S, Sabatini AG (2002) Chemical composition of European propolis: expected and unexpected results. Zeitschrift fur Naturforsch-Sect C J Biosci 57:530-533. https://doi.org/10.1515/znc-2002-5-622

Bankova V, Bertelli D, Borba R et al (2016a) Standard methods for Apis mellifera propolis research. J Apic Res. https://doi.org/10. 1080/00218839.2016.1222661

Bankova V, Popova M, Trusheva B (2016b) New emerging fields of application of propolis. Maced J Chem Chem Eng 35:1-11. https://doi.org/10.20450/mjcce.2016.864

Belwal T, Ezzat SM, Rastrelli L et al (2018) A critical analysis of extraction techniques used for botanicals: trends, priorities, industrial uses and optimization strategies. TrAC Trends Anal Chem 100:82-102. https://doi.org/10.1016/J.TRAC.2017.12.018 
Boisard S, Le Ray AM, Landreau A, Kempf M, Cassisa V, Flurin C, Richomme P (2015) Antifungal and antibacterial metabolites from a French poplar type propolis. Evid Based Complement Altern Med. https://doi.org/10.1155/2015/319240

Burdock GA (1998) Review of the biological properties and toxicity of bee propolis (propolis). Food Chem Toxicol 36:347-363. https://doi.org/10.1016/S0278-6915(97)00145-2

Curifuta M, Vidal J, Sánchez-Venegas J, Contreras A, Salazar LA, Alvear M (2012) The in vitro antifungal evaluation of a commercial extract of Chilean propolis against six fungi of agricultural importance. Cien Inv Agr 39(2):347-359

De Zordi N, Cortesi A, Kikic I et al (2014) The supercritical carbon dioxide extraction of polyphenols from propolis: a central composite design approach. J Supercrit Fluids 95:491-498. https://doi.org/10.1016/j.supflu.2014.10.006

Escriche I, Juan-Borrás M (2018) Standardizing the analysis of phenolic profile in propolis. Food Res Int 106:834-841. https:// doi.org/10.1016/j.foodres.2018.01.055

Galeotti F, Maccari F, Fachini A, Volpi N (2018) Chemical composition and antioxidant activity of propolis prepared in different forms and in different solvents useful for finished products. Foods. https://doi.org/10.3390/foods7030041

Gavanji S, Larki B (2017) Comparative effect of propolis of honey bee and some herbal extracts on Candida albicans. Chin J Integr Med 23:201-207. https://doi.org/10.1007/s11655-015-2074-9

Gniewosz M, Synowiec A, Kraśniewska K et al (2014) The antimicrobial activity of pullulan film incorporated with meadowsweet flower extracts (Filipendulae ulmariae flos) on postharvest quality of apples. Food Control 37:351-361. https://doi.org/ 10.1016/j.foodcont.2013.09.049

Gómez-Caravaca AM, Gómez-Romero M, Arráez-Román D et al (2006) Advances in the analysis of phenolic compounds in products derived from bees. $\mathrm{J}$ Pharm Biomed Anal 41:1220-1234. https://doi.org/10.1016/j.jpba.2006.03.002

Graikou K, Popova M, Gortzi O et al (2016) Characterization and biological evaluation of selected Mediterranean propolis samples. Is it a new type? LWT-Food Sci Technol 65:261-267. https://doi.org/10.1016/j.lwt.2015.08.025

Hamzah N, Leo CP (2015) Microwave-assisted extraction of Trigona propolis: the effects of processing parameters. Int J Food Eng 11:861-870. https://doi.org/10.1515/ijfe-2015-0106

Isidorov VA, Szczepaniak L, Bakier S (2014) Rapid GC/MS determination of botanical precursors of Eurasian propolis. Food Chem 142:101-106

Jug M, Končić MZ, Kosalec I (2014) Modulation of antioxidant, chelating and antimicrobial activity of poplar chemo-type propolis by extraction procures. LWT-Food Sci Technol 57:530-537. https://doi.org/10.1016/j.lwt.2014.02.006

Kartal M, Kaya S, Kurucu S (2002) GC-MS analysis of propolis from 17 different regions of Turkey. Z Naturforsch 57c:905-909

Khacha-ananda S, Tragoolpua K, Chantawannakul P, Tragoolpua Y (2013) Antioxidant and anti-cancer cell proliferation activity of propolis extracts from two extraction methods. Asian Pac J Cancer Prev 14:6991-6995. https://doi.org/10.7314/APJCP. 2013.14.11.6991

Kraśniewska K, Gniewosz M, Synowiec A, Przybył JL, Bączek K, Weeglarz Z (2015) The application of pullulan coating enriched with extracts from Bergenia crassifolia to control the growth of food microorganisms and improve the quality of peppers and apples. Food Bioprod Process 94:422-433. https://doi.org/10. 1016/j.fbp.2014.06.001

Kubiliene L, Laugaliene V, Pavilonis A et al (2015) Alternative preparation of propolis extracts: comparison of their composition and biological activities. BMC Complement Altern Med. https:// doi.org/10.1186/s12906-015-0677-5
Luján MDRM, Reséndez AM, Barrón GSG et al (2018) Antibacterial activity and phenolic content of propolis extracts obtained by different extraction methods. Nov Sci 10:397-412

Milojković-Opsenica D, Ristivojević P, Trifković J et al (2016) TLC fingerprinting and pattern recognition methods in the assessment of authenticity of poplar-type propolis. J Chromatogr Sci 54:1077-1083. https://doi.org/10.1093/chromsci/bmw024

Oni OO, Olalemi AO, Balogun OB (2018) The effect of Aloe vera gel on microorganisms associated with the deterioration of sweet orange fruits (Citrus sinensis). J Adv Microbiol 12(4):1-12

Pasupuleti VR, Sammugam L, Ramesh N, Gan SH (2017) Honey, propolis, and royal jelly: a comprehensive review of their biological actions and health benefits. Oxid Med Cell Longev. https://doi.org/10.1155/2017/1259510

Pellati F, Prencipe FP, Bertelli D, Benvenuti S (2013) An efficient chemical analysis of phenolic acids and flavonoids in raw propolis by microwave-assisted extraction combined with highperformance liquid chromatography using the fused-core technology. J Pharm Biomed Anal 81-82:126-132. https://doi.org/ 10.1016/j.jpba.2013.04.003

Popova M, Giannopoulou E, Skalicka-Woźniak K, Graikou K, Widelski J, Bankova V et al (2017) Characterization and biological evaluation of propolis from Poland. Molecules 22(7):1159

Singleton VL, Orthofer R, Lamuela-Raventós RM (1999) Analysis of total phenols and other oxidation substrates and antioxidants by means of Folin-Ciocalteu reagent. Methods Enzymol 299:152-178. https://doi.org/10.1016/S0076-6879(99)99017-1

Standards Institute Clinical Laboratory (CLSI) (2006) Performance standards for antimicrobial disk susceptibility tests; approved standard-9th ed. CLSI document M2-A9. The Clinical \& Laboratory Standards Institute, Wayne, p 26

Szliszka E, Sokół-Łętowska A, Kucharska AZ, Jaworska D, Czuba ZP, Król W (2013) Ethanolic extract of polish propolis: chemical composition and TRAIL-R2 death receptor targeting apoptotic activity against prostate cancer cells. Evid Based Complement Altern Med. https://doi.org/10.1155/2013/757628

Takasi K, Kikuni NB, Schilr H (1994) Electron microscopic and microcalorimetric investigations of the possible mechanism of the antibacterial action of propolis. Povenance Planta Med 60:222-227

Trusheva B, Trunkova D, Bankova V (2007) Different extraction methods of biologically active components from propolis: a preliminary study. Chem Cent J 1:13. https://doi.org/10.1186/ 1752-153X-1-13

Vinatoru M, Mason TJ, Calinescu I (2017) Ultrasonically assisted extraction (UAE) and microwave assisted extraction (MAE) of functional compounds from plant materials. TrAC-Trends Anal Chem 97:159-178. https://doi.org/10.1016/j.trac.2017.09.002

Yeo KL, Leo CP, Chan DJC (2015) Ultrasonic enhancement on propolis extraction at varied $\mathrm{pH}$ and alcohol content. J Food Process Eng 38:562-570. https://doi.org/10.1111/jfpe.12186

Zhang HF, Yang XH, Wang Y (2011) Microwave assisted extraction of secondary metabolites from plants: current status and future directions. Trends Food Sci Technol 22:672-688

Zhou J, Xue X, Li Y et al (2009) Multiresidue determination of tetracycline antibiotics in propolis by using HPLC-UV detection with ultrasonic-assisted extraction and two-step solid phase extraction. Food Chem 115:1074-1080. https://doi.org/10.1016/ j.foodchem.2008.12.031

Publisher's Note Springer Nature remains neutral with regard to jurisdictional claims in published maps and institutional affiliations. 